\title{
ANALISIS DEIKSIS DIALEK KULISUSU MASYARAKAT DESA RANTE GOLA KECAMATAN BONEGUNU KABUPATEN BUTON UTARA
}

\author{
Tofan Stofiana \\ Program Studi Pendidikan Bahasa dan Sastra Indonesia, Fakultas Keguruan dan Ilmu Pendidikan, \\ Universitas Muhammadiyah Buton, Jl. Betoambari No. 36 Baubau. \\ E-mail: tofanstofiana@gmail.com
}

\begin{abstract}
Abstrak
Penelitian ini bertujuan untuk mendeskripsikan Deiksis Dialek Kulisusu Masyarakat Desa Rante Gola Kecamatan Bonegunu Kabupaten Buton Utara. Metode dalam penelitian ini adalah deskriptif kualitatif. Penelitian kualitatif dilakukan dengan tidak mengutamakan angka-angka, tetapi mengutamakan kedalaman penghayatan terhadap interaksi antara konsep yang sedang dikaji secara impiris. Berdasarkan hasil penelitian ini Deiksis Dialek Kulisusu Masyarakat Desa Rante Gola Kecamatan Bonegunu Kabupaten Buton Utara yaitu: Dieksis Orang atau Persona, Dieksis Tempat, Dieksis Waktu, Dieksis Wacana, Dieksis Sosial, Dieksis Penunjuk.
\end{abstract}

Kata Kunci: analisis, deiksis, dialek.

\begin{abstract}
This study aims to describe the Kulisusu Dialectic Deixis in the Community of Rante Gola Village, Bonegunu District, North Buton Regency. The method in this study is descriptive qualitative. Qualitative research is carried out by not prioritizing numbers, but prioritizes the depth of appreciation of the interactions between concepts that are being studied imply. Based on the results of this study, Kulisusu Dialectic Deixis, Rante Gola Village Community, Bonegunu Subdistrict, North Buton Regency, namely: Dieksis People or Persona, Dieksis Place, Time Examination, Diexis Discourse, Social Diexis, Diexisator
\end{abstract}

Keywords: Analysis, Deixis, Dialect. 


\section{SANG PENCERAH}

Volume 4, Nomor 1, Agustus 2018, Hlm. 58-70

Tofan Stofiana: Analisis Deiksis Dialek Kulisusu Masyarakat ...

\section{Pendahuluan}

Bahasa merupakan medium paling penting bagi mahasiswa. Dengan bahasa mahasiswa dapat berinteraksi, bermasyarakat, dan bekerja sama dengan orang lain karena pada hakikatnya bahasa adalah alat komunikasi. Tanpa bahasa Mahasiswa tidak dapat berkomunikasi secara sempurna dalam penyampaian pesan. Santoso, (2003: 6). Fungsi utama bahasa adalah sebagai alat untuk melakukan sesuatu, meminta sesuatu, membuat janji, melaporkan suatu berita, memberi salam, meminta maaf, melarang, memberikan anjuran, mencari informasi dan mengundang seseorang di suatu acara, inilah yang disebut dengat tindak tutur.

Bahasa menunjukkan cerminan pribadi seseorang. Karakter, watak, atau pribadi seseorang dapat diidentifikasikan dari perkataan yang ia ucapkan. Penggunaan bahasa yang lemah lembut, sopan, santun, sistematis, teratur, jelas, dan lugas mencerminkan pribadi penuturnya berbudi. Sebaliknya, melalui penggunaan bahasa yang sarkasme, menghujat, memaki, memfitnah, mendiskreditkan, memprovokasi, mengejek, atau melecehkan, akan mencitrakan pribadi yang tak berbudi. Oleh karena itu dalam sebuah komunikasi yang efektif bukan hanya dibutuhkan kejernihan pesan, tapi juga kesopanan dan kesantunan berbahasa. Lakoff, (2003: 32).

Deiksis adalah kemampuan membedakan secara tepat nuansa-nuansa makna dari gagasan yang ingin disampaikan dan kemampuan menemukan bentuk yang sesuai atau cocok dengan situasi dan nilai rasa yang dimiliki kelompok masyarakat pendengar. Semua ujaran dalam tindak komunikasi selalu mengandung tiga unsur, yaitu (1) tindak lokusi berupa ujaran yang dihasilkan oleh seorang penutur, (2) tindak illokusi berupa maksud yang terkandung dalam ujaran, dan (3) tidak perlokusi berupa efek yang ditimbulkan oleh ujaran. Sejalan dengan pendapat tersebut, Searle (2005:32) menyatakan bahwa dalam satu tindak tutur sekaligus terkandung tiga macam tindakan, yaitu (1) pengujaran berupa kata atau kalimat, (2) tindak proporsional berupa acuan dan predeiksis, dan (3) tindak ilokusi dapat berupa pernyataan, pertanyaan, janji, perintah, dan sebagainya. Efek komunikatif itulah yang kadang-kadang memiliki dampak terhadap perilaku seseorang.

Berbahasa itu tidak hanya berkata-kata saja melainkan juga melakukan sesuatu yang lain, yakni penutur ingin menyampaikan maksud-maksud tertentu kepada mitra tuturnya, misalnya "saya akan meletakkan ini di sini". Tindak tutur semacam itu disebut dengan tindak tutur deiksis. Deiksis yang akan dikaji di dalam penelitian ini adalah penggunaan deiksis Dialek Kulisusu Masyarakat Desa Rante Gola Kecamatan Bonegunu Kabupaten Buton Utara. Pada dasarnya bahasa Kulisusu Masyarakat Desa Rante Gola merupakan salah satu bahasa asli Kulisusu merupakan salah satu bahasa asli Muna. Hal inilah yang menjadi alasan yang mendasar bagi peneliti untuk melakukan penelitian.

Penelitian ini dilatar belakangi oleh tiga hal pokok, yaitu penggunaan deiksis, Dialek Masyarakat Desa Rante Gola yang bersifat heterogen. Keheterogenan itu tampak dari umur, tingkat pendidikan, jenis kelamin, status sosial, dan sebagainya. Dalam hal ini masyarakat menggunakan deiksis melalui salah satu bahasa asli kulisusu dengan melihat situasi dengan siapa dia berbicara, kondisi waktu, tempat, dan tata bahasa yang digunakan harus tepat dan sesuai. Berdasarkan deskripsi di atas, fokus penelitian ini, bagaimakah Dialek Kulisusu Masyarakat Desa Rante Gola Kecamatan Bonegunu Kabupaten Buton Utara?

Tujuan penelitian ini, untuk mengetahui Dialek Kulisusu Masyarakat Desa Rante Gola Kecamatan Bonegunu Kabupaten Buton Utara. 


\section{SANG PENCERAH}

Volume 4, Nomor 1, Agustus 2018, Hlm. 58-70

Tofan Stofiana: Analisis Deiksis Dialek Kulisusu Masyarakat ...

\section{Metode Penelitian}

Metode yang dipakai dalam penelitian ini adalah metode penelitian deskriptif kualitatif. Metode ini di anggap cocok untuk penelitian satu bahasa. Penelitian ini dilakukan untuk menganalisis deiksis dialek Kulisusu terhadap masyarakat Desa Rante Gola Kecamatan Bonegunu Kabupaten Buton Utara. Jenis penelitian merupakan gambaran yang sesuai dengan keadaan yang sebenarnya. Penggumpulan informasi dilakukan dengan pertanyaan secara langsung dan pengamatan di lapangan, dengan mengunakan alat-alat observasi standar.

Sampel dalam penelitian ini adalah seluruh tuturan lisan masyarakat yang didalamnya mengandung makna atau maksud tuturan dieksis tuturanya dalam bahasa Indonesia yang terekam dalam 14 suara rekaman, yang direkam secara sembunyi-sembunyi tanpa diketahui oleh masyarakat yang diteliti. Karena jumlah populasi yang diteliti kurang dari 100 orang, maka Sampel Penelitian mengambil semua populasi untuk dijadikan sampel. Jadi sampel dalam penelitian ini berjumlah 14 orang Masyarakat Desa Rante Gola.

Teknik pengumpulan data dalam penelitian ini adalah teknik rekam dan teknik catat. Teknik rekam merupakan pemerolehan data dengan cara merekam pemakaian bahasa lisan yang bersifat spontan, sedangkan teknik catat merupakan pemerolehan data yang relevan dengan cara mencatat data sesuai dengan sasaran dan tujuan penelitian. Selain mengandalkan rekaman, peneliti juga menggunakan teknik catat sebagai alat penelitiannya. Teknik catat ini guna untuk mencatat pola tingkah laku proses komunikasi antar penutur dan mitra tutur yang terjadi dilingkungan masyarakat. Teknik catat sengaja digunakan untuk menghindari atau mencegah apabila tehnik rekaman yang digunakan tiba-tiba secara tak sengaja tidak terekam atau terhapus.
Penggunaan kedua teknik pengumpulan data tersebut peneliti lakukan untuk membuat data valid. Upaya untuk membuat agar data benar-benar valid dapat dilakukan dengan teknik triangulasi baik triangulasi data, triangulasi sumber dan triangulasi teknik atau metode. Subroto, (2002: 35). Kedua teknik tersebut peneliti pergunakan secara bersamaan untuk saling mengecek, mengisi, melengkapi, serta dendukung pengumpulan data.

Berdasarkan pendekatan yang dipergunakan maka metode analisis data yang digunakan adalah metode kontekstual. Metode kontekstual merupakan cara analisis yang diterapkan pada data dengan mendasarkan, perhitungan dan mengaitkan konteks. Rahardi, (2000: 14). Sebelum data dianalisis dengan menggunakan metode kontekstual, terlebih dahulu data-data yang menyangkut tentang penelitian mengenai penggunaan tindak tutur dengan mengaitkan deiksis terhadap sopan santun masyarakat. Penelitian ini dimaksudkan agar kegiatan penelitian ini dapat benarbenar menjadi objektif untuk mendapatkan penggunaan tindak tutur dengan mengaitkan deiksis terhadap sopan santun masyarakat. Sehingga dapat berjalan secara ilmiah atau mendapat data yang akurat.

\section{Pembahasan}

Deiksis adalah kemampuan membedakan secara tepat nuansa-nuansa makna dari gagasan yang ingin disampaikan dan kemampuan menemukan bentuk yang sesuai atau cocok dengan situasi dan nilai rasa yang dimiliki kelompok masyarakat pendengar. Dalam penelitian diatas penulis lebih menspesifikasikan hal-hal yang menyangkut tentang tindak tutur yang diutarakan oleh masyarakat dengan melihat kaidah Dialek berbahasanya. Sehingga dalam hal ini akan dijabarkan deiksis bahasa yang diutarakan masyarakat dengan melihat 


\section{SANG PENCERAH}

Volume 4, Nomor 1, Agustus 2018, Hlm. 58-70

Tofan Stofiana: Analisis Deiksis Dialek Kulisusu Masyarakat ...

Dialek Kulisusu Masyarakat Desa Rante Gola Kecamatan Bonegunu Kabupaten Buton Utara. Dalam hal ini penulis lebih melihat pada kondisi dieksisnya yang terdapat pada enam dieksis sebagai bentuk pengucapan tindak tutur bahasanya terhadap Dialek kulisusu, diantaranya ialah, Dieksis orang atau persona, tempat, waktu, wacana, sosial, dan dieksis penunjuk.

\section{Deiksis Orang atau Persona}

Penelitian ini dilakukan pada dua situasi berbeda, peneliti melakukan pencarian data berdasarkan Deiksis orang atua persona pada Dialek Kulisusu, Desa Rante Gola Kecamatan Bonegunu Kabupaten Buton Utara, pertama dalam situasi pagi pada pukul 08.00, ibu-ibu ingin berbelanja dipasar Rantegola dan situasi kedua yaitu seorang mahasiswa yang masih berlibur di kampung. Adapun kutipan deiksis ini sebagai berikut:

Responden 01 :

Ina, meanta tolako idaoano Rante Gola, ako tolako peronga-ronga

Pada kalimat di atas, menunjukan Deiksis Orang atau Persona pada Dialek Kulisusu Masyarakat Desa Rante Gola, bahwa Responden 01 menyatakan dieksis persona karena menegaskan pernyataan, atau bertanya kepada seorang Ibu bahwa Ibu, Besok kita pergi dipasar (Rantegola), nanti kita sama-sama pergi. Maka dari Dialek orang atau persona mengatakan sebagai satu bentuk bahasa yang digunakan dalam suatu daerah atau dalam sebuah kondisi masyarakat.

Responden 02 :

Responden 04 : Hiina ina, meanta ungkude kupojagaipo ana kaasi. Biasano miarahangku ilako isikolah, ako keimembali wakuu nsuere, kei jadi mimengertipo lae.
Pada kalimat di atas, menunjukan Deiksis Orang atau Persona pada Dialek Kulisusu Masyarakat Desa Rante Gola, bahwa Responden 02 menyatakan dieksis persona karena menegaskan pertanyaan responden 01 dalam menjawab kondisinya bahwa Tidak Ibu, besok saya lagi jaga anak kasian. Biasa suamiku pergi kesekolah, nanti mi lain kali aja, mengerti saja. Maka dari Dialek orang atau persona mengatakan sebagai satu bentuk bahasa yang digunakan dalam sebuah kondisi masyarakat.

\section{Deiksis Tempat}

Penelitian ini dilakukan pada situasi mahasiswa yang telah berlibur di desa Wantigola, peneliti melakukan pencarian data berdasarkan Deiksis tempat pada Dialek Kulisusu, Desa Rante Gola Kecamatan Bonegunu Kabupaten Buton Utara, dalam situasi ini mereka sedang membahas lamanya tidak bertemu, dan merenakan sebuah pertemuan untuk temantemannya. Adapun kutipan deiksis ini sebagai berikut:

Responden 03:

Ingkoo ai hapai kau molaa tou tokompulukompulu mbule lae...

Pada kalimat di atas, menunjukan deiksis tempat Dialek Kulisusu Masyarakat Desa Rante Gola, bahwa Responden 03 menyatakan dieksis tempat karena menegaskan pernyataan bahwa Ko ini kenapa ko jarang sekali kita ngumpul lagi e.... Kata kumpul menunjukan deiksis tempat yaitu pemberian bentuk pada lokasi dalam peristiwa bahasa atau sebuah lokasi yang akan dituju untuk berkumpul.

Itahino membuku iokuda teyo vila rouno imokesa pemandanganno.

\section{Deiksis Waktu}

Penelitian ini dilakukan pada situasi mahasiswa yang telah berlibur di desa Wantigola, peneliti melakukan pencarian 


\section{SANG PENCERAH}

Volume 4, Nomor 1, Agustus 2018, Hlm. 58-70

\section{Tofan Stofiana: Analisis Deiksis Dialek Kulisusu Masyarakat ...}

data berdasarkan Deiksis waktu pada Dialek Kulisusu, Desa Rante Gola Kecamatan Bonegunu Kabupaten Buton Utara, dalam situasi ini mereka sedang membahas informasi masuk kuliah. Adapun kutipan deiksis ini sebagai berikut:

Responden 06:

Memangno meanta ai tousu kumarajaa jam sahapa

Pada kalimat di atas, menunjukan deiksis waktu Dialek Kulisusu Masyarakat Desa Rante Gola, bahwa Responden 06 menyatakan dieksis waktu karena menegaskan pernyataan bahwa memang besok kita masuk kerja jam berapa. Kata jam menunjukan deiksis waktu yaitu pemberian bentuk pada rentang waktu seperti yang dimaksudkan penutur dalam peristiwa bahasa.

Responden 07:

Mentee jam satu

Pada kalimat di atas, menunjukan deiksis waktu Dialek Kulisusu Masyarakat Desa Rante Gola, bahwa Responden 07 menyatakan dieksis waktu karena menegaskan pernyataan bahwa kemungkinan jam satu. Kata jam satu menunjukan deiksis waktu yaitu pemberian bentuk pada rentang waktu seperti yang dimaksudkan penutur dalam peristiwa bahasa.

Responden 08:

Dayimpia ingkita betolako idaoa rouno betopolo giu-giuno boninahu

Pada kalimat di atas, menunjukan deiksis waktu Dialek Kulisusu Masyarakat Desa Rante Gola, bahwa Responden 08 menyatakan dieksis waktu karena menegaskan pernyataan bahwa jadi kapan kita kepasar untuk membeli bahan-bahan untuk memasak. Kata kapan menunjukan deiksis waktu yaitu pemberian bentuk pada rentang waktu seperti yang dimaksudkan penutur dalam peristiwa bahasa.

Responden 06:

Mentee oleono ahadti rouno i ompole marasano te ingkita duka topentaa.

Pada kalimat di atas, menunjukan deiksis waktu Dialek Kulisusu Masyarakat Desa Rante Gola, bahwa Responden 06 menyatakan dieksis waktu karena menegaskan pernyataan bahwa nanti hari minggu saja soalnya banyak yang menjual, kebetulan kita libur. Kata hari minggu menunjukan deiksis waktu yaitu pemberian bentuk pada rentang waktu seperti yang dimaksudkan penutur dalam peristiwa bahasa.

Responden 07:

Da samingguno ai ingkita beto ujan final lae

Pada kalimat di atas, menunjukan deiksis waktu Dialek Kulisusu Masyarakat Desa Rante Gola, bahwa Responden 07 menyatakan dieksis waktu karena menegaskan pernyataan bahwa satu minggu lagi kita ujian final. Kata satu minggu menunjukan deiksis waktu yaitu pemberian bentuk pada rentang waktu seperti yang dimaksudkan penutur dalam peristiwa bahasa.

Responden 06:

Taeono Ririn i wula i ouaiko beto pentaa lembahi

Pada kalimat di atas, menunjukan deiksis waktu Dialek Kulisusu Masyarakat Desa Rante Gola, bahwa Responden 06 menyatakan dieksis waktu karena menegaskan pernyataan bahwa katanya Ririn bulan depan kita libur panjang. Kata bulan depan menunjukan deiksis waktu yaitu pemberian bentuk pada rentang waktu seperti yang dimaksudkan penutur dalam peristiwa bahasa. 


\section{SANG PENCERAH}

Volume 4, Nomor 1, Agustus 2018, Hlm. 58-70

Tofan Stofiana: Analisis Deiksis Dialek Kulisusu Masyarakat ...

Responden 07:

Kobangu ingkita ai betoari mewawo ewo ai jam lima ompudu oleo

Pada kalimat di atas, menunjukan deiksis waktu Dialek Kulisusu Masyarakat Desa Rante Gola, bahwa Responden 07 menyatakan dieksis waktu karena menegaskan pernyataan bahwa kayanya kita selesai cabut rumput ini jam lima sore. Kata jam lima sore menunjukan deiksis waktu yaitu pemberian bentuk pada rentang waktu seperti yang dimaksudkan penutur dalam peristiwa bahasa.

Pada kalimat di atas, menunjukan deiksis tempat Dialek Kulisusu Masyarakat Desa Rante Gola, bahwa Responden 04 menyatakan dieksis tempat karena menegaskan pernyataan bahwa Di pantai membuku dekat dengan vila saja, karena pemandanganya sangat indah. Kata dekat vila menunjukan deiksis tempat yaitu pemberian bentuk pada lokasi dalam peristiwa bahasa atau sebuah lokasi yang akan dituju untuk berkumpul.

Responden 05 :

Leumo tolako to aca-acara pekancunuika $i$ empang rouno riasoa i mewalo ikano.

Pada kalimat di atas, menunjukan deiksis tempat Dialek Kulisusu Masyarakat Desa Rante Gola, bahwa Responden 05 menyatakan dieksis tempat karena menegaskan pernyataan bahwa mari kita pergi acara bakar-bakar ikan di empang karna disana enak ikannya. Kata empang menunjukan deiksis tempat yaitu pemberian bentuk pada lokasi dalam peristiwa bahasa.

Responden 03 :

I bendungan $i$ ompoletou mia mengkabahobahono te duka indade lembahimo ndo pebaho ahirino kamapunamo

Pada kalimat di atas, menunjukan deiksis tempat Dialek Kulisusu Masyarakat Desa Rante Gola, bahwa Responden 03 menyatakan dieksis tempat karena menegaskan pernyataan bahwa di bendungan banyak sekali yang mandimandi, dan mereka lantaran kelamaan mandi lalu mereka kedinginan. Kata bendungan menunjukan deiksis tempat yaitu pemberian bentuk pada lokasi dalam peristiwa bahasa.

Responden 05:

Irahano Ani meto diskusi soalano iriasoa ilalesa ruanganno te duka nahina $i$ ompole mia masagono.

Pada kalimat di atas, menunjukan deiksis tempat Dialek Kulisusu Masyarakat Desa Rante Gola, bahwa Responden 05 menyatakan dieksis tempat karena menegaskan pernyataan bahwa di rumahnya Ani tempatnya untuk berdiskusi soalnya disana luas ruanganya dan tidak banyak orang yang ribut. Kata kamar mandi menunjukan deiksis tempat yaitu pemberian bentuk pada lokasi dalam peristiwa bahasa.

Responden 01 :

o kuaikokah, kengkaiko ungkude bokulako duka samia-miangkuduka e... wa tei daa kusi-kusi duka ai.

Pada kalimat di atas, menunjukan Deiksis Orang atau Persona pada Dialek Kulisusu Masyarakat Desa Rante Gola, bahwa Responden 01 menyatakan dieksis persona karena menegaskan pertanyaan responden 02 lagi dalam menjawab kondisinya bahwa Begitukah, kalau begitu saya pergi sendiri lagi e... wah sunyi juga ini. Maka dari Dialek orang atau persona mengatakan sebagai satu bentuk bahasa yang digunakan dalam sebuah kondisi masyarakat.

Responden 03 :

Tosepakatiomo, rouno ingkita betopentaa ai. Mentee duka nahina betobaawa. Ako topentaa okuda tolu wula iso, aisomo mentee ingkita hinaamo betosauri bumaawa. 


\section{SANG PENCERAH}

Volume 4, Nomor 1, Agustus 2018, Hlm. 58-70

Tofan Stofiana: Analisis Deiksis Dialek Kulisusu Masyarakat ...

Pada kalimat di atas, menunjukan Deiksis Orang atau Persona pada Dialek Kulisusu Masyarakat Desa Rante Gola, bahwa Responden 03 menyatakan dieksis persona karena menegaskan pernyataan bahwa Sepakat, apalagi kita mau liburan ini, tidakmunkin kita bisa ketemu lagi, liburanya kan hampir tiga bulan itu jadi jarang kita bisa ketemu lagi. Maka dari Dialek orang atau persona mengatakan sebagai satu bentuk bahasa yang digunakan dalam suatu daerah atau suatu kelas sosial.

Responden 04 :

Kengkaiko ungkude kulingkamo aripo kato ba'awa-awa duka lae, ako kato bakumpulu i suere hanomo.

Pada kalimat di atas, menunjukan Deiksis Orang atau Persona pada Dialek Kulisusu Masyarakat Desa Rante Gola, bahwa Responden 04 menyatakan dieksis persona karena menegaskan pernyataan bahwa Kalau gitu saya berangkat saja nati kapan-kapan kita bertemu lagi ok. Tapi nati kalau kita berkumpul, di tempat lain saja. Maka dari Dialek orang atau persona mengatakan sebagai satu bentuk bahasa yang digunakan dalam suatu daerah atau suatu kelas sosial.

\section{Deiksis Wacana}

Penelitian ini dilakukan untuk mencari data berdasarkan Deiksis wacana pada Dialek Kulisusu, Desa Rante Gola Kecamatan Bonegunu Kabupaten Buton Utara, Deiksis wacana ialah rujukan pada bagian-bagian tertentu dalam wacana yang telah diberikan atau sedang dikembangkan. Deiksis wacana mencakup anafora dan katafora. Adapun kutipan deiksis ini sebagai berikut:

\section{Anafora}

Adapun kutipan dalam wacana Anafora sebagai berikut:
1) Pinolitamangku iteleu minai kampo inindua teduka ipowawa hasilino pombulaa

Pada kalimat di atas, menunjukan deiksis wacana Anafora pada Dialek Kulisusu Masyarakat Desa Rante Gola, bahwa Paman datang dari desa kemarin dengan membawa hasil palawijaya. Kalimat di atas menunjukan deiksis wacana Anafora yaitu penunjukan kembali kepada sesuatu yang telah disebutkan sebelumnya dalam wacana dengan pengulangan atau substitusi.

2) Rouno woono imoiko, maka iopoo ayiko iomple ndo pooli

Pada kalimat di atas, menunjukan deiksis wacana Anafora pada Dialek Kulisusu Masyarakat Desa Rante Gola, bahwa Karena dengan aromanya yang khas, maka mangga itu banyak yang dibeli. Kalimat di atas menunjukan deiksis wacana Anafora yaitu penunjukan kembali kepada sesuatu yang telah disebutkan sebelumnya dalam wacana dengan pengulangan atau substitusi.

3) Andingku kadipo keiteleu minai kotano Bandung, rouno idade kadipo keyiari kuliano.

Pada kalimat di atas, menunjukan deiksis wacana Anafora pada Dialek Kulisusu Masyarakat Desa Rante Gola, bahwa Adikku baru pulang baru pulang dari kota bandung, karena baru menyelesaiakan studinya disana. Kalimat di atas menunjukan deiksis wacana Anafora yaitu penunjukan kembali kepada sesuatu yang telah disebutkan sebelumnya dalam wacana dengan pengulangan atau substitusi.

4) Kou teleu minai kota iso, maka ingkoo iko tabeano mou koto-toropo ilaro raha

Pada kalimat di atas, menunjukan deiksis wacana Anafora pada Dialek Kulisusu Masyarakat Desa Rante Gola, bahwa Kalau datang dari kota itu, maka itu harus tenag-tenang dulu dalam 


\section{SANG PENCERAH}

Volume 4, Nomor 1, Agustus 2018, Hlm. 58-70

Tofan Stofiana: Analisis Deiksis Dialek Kulisusu Masyarakat ...

rumah. Kalimat di atas menunjukan deiksis wacana Anafora yaitu penunjukan kembali kepada sesuatu yang telah disebutkan sebelumnya dalam wacana dengan pengulangan atau substitusi.

5) Pinolicina inindua ilako idaoa ipooli pinenbulu.

Pada kalimat di atas, menunjukan deiksis wacana Anafora pada Dialek Kulisusu Masyarakat Desa Rante Gola, bahwa Bibi kemarin pagi kepasar degan membeli sayur. Kalimat di atas menunjukan deiksis wacana Anafora yaitu penunjukan kembali kepada sesuatu yang telah disebutkan sebelumnya dalam wacana dengan pengulangan atau substitusi.

\section{Katafora}

Adapun kutipan dalam wacana Anafora sebagai berikut:

1) Ingkoo yoa'ayi tabeano boupowawa iyotongkat isikolah meanta jam 7 mewangu, te isee u terlambat

Pada kalimat di atas, menunjukan deiksis wacana Katafora pada Dialek Kulisusu Masyarakat Desa Rante Gola, bahwa Yang berikut kamu harus membawa tongkat disekolah, besok pada jam 7 pagi, dan jangan terlambat. Kalimat di atas menunjukan deiksis wacana Katafora yaitu penunjukan ke sesuatu yang disebut kemudian atau yang akan disebut.

\section{2) Ipadaai ingkoo tabeano uweweuopo beitonia ako}

Pada kalimat di atas, menunjukan deiksis wacana Katafora pada Dialek Kulisusu Masyarakat Desa Rante Gola, bahwa Di bawah ini kamu harus memperbaikinya dengan benar. Kalimat di atas menunjukan deiksis wacana Katafora yaitu penunjukan ke sesuatu yang disebut kemudian atau yang akan disebut.
3) Giu-giu bo ingkita ginaunto ako ai

Pada kalimat di atas, menunjukan deiksis wacana Katafora pada Dialek Kulisusu Masyarakat Desa Rante Gola, bahwa jenis-jenis yang mau kita bicarakan adalah sebagai berikut. Kalimat di atas menunjukan deiksis wacana Katafora yaitu penunjukan ke sesuatu yang disebut kemudian atau yang akan disebut.

4) Yoa"ayai giu-giuno masaalah bo ginaunto akoayai

Pada kalimat di atas, menunjukan deiksis wacana Katafora pada Dialek Kulisusu Masyarakat Desa Rante Gola, bahwa yang termasuk jenis-jenis masaalah yang akan adalah sebagai berikut. Kalimat di atas menunjukan deiksis wacana Katafora yaitu penunjukan ke sesuatu yang disebut kemudian atau yang akan disebut.

5) Bo yoa'ayi umusuno giu-giuno deiksis

Pada kalimat di atas, menunjukan deiksis wacana Katafora pada Dialek Kulisusu Masyarakat Desa Rante Gola, bahwa yang termaksud jenis-jenis deiksis antara lain. Kalimat di atas menunjukan deiksis wacana Katafora yaitu penunjukan ke sesuatu yang disebut kemudian atau yang akan disebut.

\section{Deiksis Sosial}

Penelitian ini dilakukan untuk mencari data berdasarkan Deiksis sosial pada Dialek Kulisusu, Desa Rante Gola Kecamatan Bonegunu Kabupaten Buton Utara, terdapat penelitian seorang guru dan pedang telah berdialog pada kegiatan masyarakat Desa Rantegola. Adapun kutipan deiksis ini sebagai berikut:

Responden 09:

Impia ingkita meto mulai rumapat ai? 


\section{SANG PENCERAH}

Volume 4, Nomor 1, Agustus 2018, Hlm. 58-70

Tofan Stofiana: Analisis Deiksis Dialek Kulisusu Masyarakat ...

Pada kalimat di atas, menunjukan deiksis sosial Dialek Kulisusu Masyarakat Desa Rante Gola, bahwa Responden 09 menyatakan dieksis waktu karena menegaskan pernyataan bahwa Kapan kita mulai rapatnya. Kalimat ini ucapakan oleh seorang guru menunjukan deiksis sosial yaitu rujukan yang dinyatakan berdasarkan perbedaan kemasyarakatan yang mempengaruhi peran pembicara dan pendengar. Perbedaan itu dapat ditunjukkan dalam pemilihan kata. Dalam beberapa bahasa, perbedaan tingkat sosial antara pembicara dengan pendengar yang diwujudkan dalam seleksi kata dan atau sistem morfologi kata-kata tertentu.

Responden 10 :

Kengkaiko ingkita keto arimo kumompulu pak seharusno tokumpulu saluwukita, ariako ingkita to mulai rapatno, kehina duka to sokoriindapo te wali-walihako duka mpriou, rouno dahopuluh $\mathrm{ka}$ olima menitno duka yorapatto

Pada kalimat di atas, menunjukan deiksis sosial Dialek Kulisusu Masyarakat Desa Rante Gola, bahwa Responden 10 menyatakan dieksis waktu karena menegaskan pernyataan bahwa Kalau kita sudah kumpul pak seharusnya terkumpul dulu semua, baru kita mulai mi rapatnya, atau nanti tunggu teman-teman saja mi dulu, kan 15 menit lagi kita rapatnya. Kalimat ini ucapakan oleh seorang pedagang menunjukan deiksis sosial yaitu rujukan yang dinyatakan berdasarkan perbedaan kemasyarakatan yang mempengaruhi peran pembicara dan pendengar. Perbedaan itu dapat ditunjukkan dalam pemilihan kata. Dalam beberapa bahasa, perbedaan tingkat sosial antara pembicara dengan pendengar yang diwujudkan dalam seleksi kata dan atau sistem morfologi kata-kata tertentu.

Responden 09 :

I jadi, ingkita topesikori te wali-wali hako dahopuluh kaolima menitno, kehinna ndotele ingkita to mulaimo rumapat.
Pada kalimat di atas, menunjukan deiksis sosial Dialek Kulisusu Masyarakat Desa Rante Gola, bahwa Responden 09 menyatakan dieksis waktu karena menegaskan pernyataan bahwa Boleh, kita menunggu teman-teman 15 menit lagi, kalau mereka tidak datang kita mulai saja rapatnya. Kalimat ini ucapakan oleh seorang guru menunjukan deiksis sosial yaitu rujukan yang dinyatakan berdasarkan perbedaan kemasyarakatan yang mempengaruhi peran pembicara dan pendengar. Perbedaan itu dapat ditunjukkan dalam pemilihan kata. Dalam beberapa bahasa, perbedaan tingkat sosial antara pembicara dengan pendengar yang diwujudkan dalam seleksi kata dan atau sistem morfologi kata-kata tertentu.

Responden 10 :

Ummbe pak, indade ai ilombahi duka kendoteleu. Iya pak, mereka ini lamanya juga datang...

Pada kalimat di atas, menunjukan deiksis sosial Dialek Kulisusu Masyarakat Desa Rante Gola, bahwa Responden 10 menyatakan dieksis waktu karena menegaskan pernyataan bahwa Iya pak, mereka ini lamanya juga datang. Kalimat ini ucapakan oleh seorang pedagang menunjukan deiksis sosial yaitu rujukan yang dinyatakan berdasarkan perbedaan kemasyarakatan yang mempengaruhi peran pembicara dan pendengar. Perbedaan itu dapat ditunjukkan dalam pemilihan kata. Dalam beberapa bahasa, perbedaan tingkat sosial antara pembicara dengan pendengar yang diwujudkan dalam seleksi kata dan atau sistem morfologi kata-kata tertentu.

\section{Deiksis Penunjuk}

Penelitian ini dilakukan untuk mencari data berdasarkan Deiksis penunjuk pada Dialek Kulisusu, Desa Rante Gola Kecamatan Bonegunu Kabupaten Buton Utara, terdapat penelitian dua remaja yang 


\section{SANG PENCERAH}

Volume 4, Nomor 1, Agustus 2018, Hlm. 58-70

\section{Tofan Stofiana: Analisis Deiksis Dialek Kulisusu Masyarakat ...}

sedang berdiskusi. Adapun kutipan deiksis ini sebagai berikut:

Responden 11:

Tei ompole masaalau iko

Pada kalimat di atas, menunjukan deiksis penunjuk Dialek Kulisusu Masyarakat Desa Rante Gola, bahwa Responden 11 menyatakan dieksis penunjuk karena menegaskan pernyataan bahwa Banyaknya masalahmu itu. Kata itu menunjukan deiksis penunjuk yaitu kata ganti penunjuk "ini" untuk menunjuk sesuatu yang dekat dengan penutur, dan "itu" untuk menunjuk sesuatu yang jauh dari pembicara. "Sesuatu" itu bukan hanya benda atau barang melainkan juga keadaan, peristiwa, bahkan waktu.

Responden 12:

Isee $u$ atu-aturu mia, marako $k u$ didiuko kupompake helem yaai.

Pada kalimat di atas, menunjukan deiksis penunjuk Dialek Kulisusu Masyarakat Desa Rante Gola, bahwa Responden 12 menyatakan dieksis penunjuk karena menegaskan pernyataan bahwa Jangan ko atur-atur orang, nanti saya pukul kau pake helm ini. Kata ini menunjukan deiksis penunjuk yaitu kata ganti penunjuk "ini" untuk menunjuk sesuatu yang dekat dengan penutur, dan "itu" untuk menunjuk sesuatu yang jauh dari pembicara. "Sesuatu" itu bukan hanya benda atau barang melainkan juga keadaan, peristiwa, bahkan waktu.

Responden 11:

Iseepo mperiu u emosi ntaanu, memangno masaalau iko imomuna paselesaiano lede?

Pada kalimat di atas, menunjukan deiksis penunjuk Dialek Kulisusu Masyarakat Desa Rante Gola, bahwa Responden 11 menyatakan dieksis penunjuk karena menegaskan pernyataan bahwa Jangan dulu ko emosi dan, Memangnya masalahmu itu bisa di selesaikan dengan mudah?. Kata itu menunjukan deiksis penunjuk yaitu kata ganti penunjuk "ini" untuk menunjuk sesuatu yang dekat dengan penutur, dan "itu" untuk menunjuk sesuatu yang jauh dari pembicara. "Sesuatu" itu bukan hanya benda atau barang melainkan juga keadaan, peristiwa, bahkan waktu.

Responden 12:

Masaalano gau'u iko, nahina iusu akala, mohapa duka kau polaha cumampuru torusu, rouno masaalangku inao masaalau, ingkoo polaha cumampuru torusu, arimo, arimo iseemo mpole gaau.

Pada kalimat di atas, menunjukan deiksis penunjuk Dialek Kulisusu Masyarakat Desa Rante Gola, bahwa Responden 12 menyatakan dieksis penunjuk karena menegaskan pernyataan bahwa Masalah bicaramu itu, tidak masuk akal, untuk apa juga ko ikut campur, kan masalahku bukan masalahmu, ko ikut campur terus, sudah, sudah jangan banyak bicaramu. Kata itu menunjukan deiksis penunjuk yaitu kata ganti penunjuk "ini" untuk menunjuk sesuatu yang dekat dengan penutur, dan "itu" untuk menunjuk sesuatu yang jauh dari pembicara. "Sesuatu" itu bukan hanya benda atau barang melainkan juga keadaan, peristiwa, bahkan waktu.

Responden 11:

Santaimo lae, ingkita kadio gumai ai, ntaanu ingkita ijadi topekabantu to?

Pada kalimat di atas, menunjukan deiksis penunjuk Dialek Kulisusu Masyarakat Desa Rante Gola, bahwa Responden 11 menyatakan dieksis penunjuk karena menegaskan pernyataan bahwa Santai mi dan, kita hanya bicara saja ini, kan sebagai teman kita bisa saling membantu kah? Kata ini menunjukan deiksis penunjuk yaitu kata ganti penunjuk "ini" untuk menunjuk 


\section{SANG PENCERAH}

Volume 4, Nomor 1, Agustus 2018, Hlm. 58-70

Tofan Stofiana: Analisis Deiksis Dialek Kulisusu Masyarakat ...

sesuatu yang dekat dengan penutur, dan "itu" untuk menunjuk sesuatu yang jauh dari pembicara. "Sesuatu" itu bukan hanya benda atau barang melainkan juga keadaan, peristiwa, bahkan waktu.

Responden 11:

Ingkoo ayi, kadi tokuaniko iso

Pada kalimat di atas, menunjukan deiksis penunjuk Dialek Kulisusu Masyarakat Desa Rante Gola, bahwa Responden 11 menyatakan dieksis penunjuk karena menegaskan pernyataan bahwa Kau ini, kita kasi tau saja ini. Kata ini menunjukan deiksis penunjuk yaitu kata ganti penunjuk "ini" untuk menunjuk sesuatu yang dekat dengan penutur, dan "itu" untuk menunjuk sesuatu yang jauh dari pembicara. "Sesuatu" itu bukan hanya benda atau barang melainkan juga keadaan, peristiwa, bahkan waktu.

\section{Simpulan}

Simpulan penelitian ini adalah bahwa analisis Deiksis Dialek Kulisusu Masyarakat Desa Rante Gola Kecamatan Bonegunu Kabupaten Buton Utara yaitu: Deiksis Orang atau Persona pada Dialek Kulisusu Masyarakat Desa Rante Gola Kecamatan Bonegunu Kabupaten Buton Utara yang dilakukan sebanyak 3 Responden yaitu responden 01 , responden 02 , dan responden 03. Penuturan tersebut menjelaskan bahwa masing-masing responden merujuk pembicara kepada dirinya atau kelompok yang melibatkan dirinya. Deiksis Tempat pada Dialek Kulisusu Masyarakat Desa Rante Gola Kecamatan Bonegunu Kabupaten Buton Utara yang dilakukan sebanyak 3 Responden yaitu responden 04, responden 05, dan responden 06. Penuturan tersebut menjelaskan bahwa masing-masing responden mengacu ke suatu tempat.

Deiksis Waktu pada Dialek Kulisusu Masyarakat Desa Rante Gola Kecamatan
Bonegunu Kabupaten Buton Utara yang dilakukan sebanyak 3 Responden yaitu responden 06, responden 07, dan responden 08. Penuturan tersebut menjelaskan bahwa masing-masing responden mengacu kepada rentang waktu seperti yang dimaksudkan penutur dalam peristiwa bahasa.

Deiksis Wacana pada Dialek Kulisusu Masyarakat Desa Rante Gola Kecamatan Bonegunu Kabupaten Buton Utara yang dilakukan sebanyak 10 kutipan masingmasing dari Deiksis Wacana terdapat 5 kutipan yaitu 5 kutipan wacana anafora dan 5 kutipan wacana katafora. Penuturan tersebut menjelaskan bahwa masing-masing responden mengacu penunjukan kembali kepada sesuatu yang telah disebutkan sebelumnya dalam wacana dengan pengulangan atau substitusi.

Deiksis Sosial pada Dialek Kulisusu Masyarakat Desa Rante Gola Kecamatan Bonegunu Kabupaten Buton Utara yang dilakukan sebanyak 2 Responden yaitu responden 09, dan responden 10. Penuturan tersebut menjelaskan bahwa masing-masing responden mengacu kepada rujukan yang dinyatakan berdasarkan perbedaan kemasyarakatan yang mempengaruhi peran pembicara dan pendengar.

Deiksis Penunjuk pada Dialek Kulisusu Masyarakat Desa Rante Gola Kecamatan Bonegunu Kabupaten Buton Utara yang dilakukan sebanyak 2 Responden yaitu responden 11, dan responden 12. Penuturan tersebut menjelaskan bahwa masing-masing responden mengacu kepada rujukan yang dinyatakan berdasarkan perbedaan kemasyarakatan yang mempengaruhi peran pembicara dan pendengar. 


\section{SANG PENCERAH}

Volume 4, Nomor 1, Agustus 2018, Hlm. 58-70

Tofan Stofiana: Analisis Deiksis Dialek Kulisusu Masyarakat ...

\section{Daftar Pustaka}

Agustina, Mey. 2005. Penyajian Tindak Tuturan Prakmatik. Jakarta: Divva Pres.

Brown, Gillian dan Yule., George. 2006. Analisis Wacana. Jakarta: PT Gramedia Pustaka Utama.

Chaer, Abdul. 2010. Prakmatik. Jakarta: Pustaka Utama.

Depdiknas. 2008. Kamus Besar Bahasa Indonesia. Jakarta: PT Rieneka Cipta.

Hasan Alwi dkk. 2008. Tata Bahasa Baku Bahasa Indonesia. Jakarta: Balai Pustaka.

Clark, Herbert H. 2007. IlmuPragmatik: Teori dan Penerapannya. Jakarta: Depdikbud.

Hudson. 2008. "Bahasa dan Linguistik," Pesona Bahasa: Langkah Awal Memahami Linguistik. ed. Kushartanti, Untung Yuwono, dan Multamia RMT Lauder. Jakarta: Gramedia.

J.K. Chamber. 1990. Pengajaran Bahasa Komunikatif. Purwokerto: Pustaka Pelajar

Kamaruddin. 1997. Gaya Bahasa. Jakarta: PT Gramedia Pustaka Utama

Lakoff, 2003. Penyajian Penggunaan Bahasa Indonesia. Jakarta Press.

Leech, Geoffrey. 2003. Kajian Tindak Tutur. Surabaya: Uasaha Nasional.

Levinson, Stephent C. 1983. Pragmatics. Cambridge: Cambridge UnivercityPress.

Mansur, Hudson. 2003. Pengantar Ilmu Komunikasi. Jakarta: Rajawali Press

Mazlan, Suarjin. 2007. Dasar-dasar Kajian Sastra dan Penerapannya. Yogyakarta: Kanisius
Nababan. 2007. Ilmu Pragmatik. Jakarta: Depdikbud.

Nik, Safiah, Karim. 2003. Pengajaran Semantik. Bandung: Angkasa.

Oktavianus, Samsuri, 2010, Analisis Bahasa.Jakarta: Erlangga.

Purwo, Rival. 2004. Pragmatik. Kesantunan Imperatif Bahasa Indonesia. Jakarta: Erlangga

Retonningsi. 2012. Ikhtisar Sejarah Sastra Indonesia. Bandung: Binacipta.

Rusyana. 2004. Tindak Tutur dan Berbahasa. Jakarta: Sinnar Jaya

Rogers, Lous. 2001. Analision Linguistik Produksi. Asutria: Manger.

Santoso, 2003. Pelaksanaan Pembelajaran Bahasa Indonesia. Bandung: Pustaka Press.

Subroto, Wihaya. 2002. Analisis Penelitian Kebahasaan. Jakarta: Fiks Kelas.

Sudaryat, Ndang. 2006. Ringkasan Bahasa Indonesia. Bandung: Ganeca Exact Bandung.

Sukriswati. 2008. Tentang sastra. Jakarta: Intermasa. (Terjemahan Akhdiati Ikram)

Sumarsono. 2002."Etika dan Tatakrama Dahulu dan Masa Kini", Keadaan dan Perkembangan Bahasa, Sastra, Etika, Tatakrama, dan Seni Pertunjukan.

Suharso, 2002. Analisis Sastra Tingkat Mahasiswa. Jakarta: Departemen Pendidikan dan Kebudayaan

Setianingrum, Nani. 2003. Tindak Tutur Bahasa Indonesia .Malang: Skripsi UMM. 


\section{SANG PENCERAH}

Volume 4, Nomor 1, Agustus 2018, Hlm. 58-70

Tofan Stofiana: Analisis Deiksis Dialek Kulisusu Masyarakat ...

Setiawan, 2007. Dasar dan Konsep Pendidikan. Jakarta: Diva Pres.

Tarigan, Gundur Henry. 2000. Pengajaran Kompetensi Bahasa. Bandung:Angkasa Bandung.

Wijana, Dewa Putu. 2006. Dasar-Dasar Penelitian Pragmatik. Yogyakarta: Andi Offset. 